Avaliable online at: http://www.syekhnurjati.ac.id/jurnal/index.php/ijas/index DOI : 10.24235/ijas.v2i1.5437

Published by Departement of Arabic Language and Literature, Faculty of Adab IAIN Syekh Nurjati Cirebon, Indonesia

\title{
AIR MENSUCIKAN DAN MENAJISKAN PADA NASKAH MUQADDIMAH IMAM BAFADAL AL-HADRAMY KARYA AL- HAITAMI (TINJAUAN FILOLOGI)
}

\author{
Muhammad Dedad Bisaraguna Akastangga \\ gunabisara@gmail.com
}

Universitas Nahdlatul Wathan Mataram

- Received: 21.11.2019 • Accepted: 30.04.2020 • Published online: 05.05.2020

\begin{abstract}
Syarah Muqoddimah al-Imam Bafadal al-Hadrami By al-Haitami is a single manuscript. The problem in this study is to find out the sound of the text of the manuscript and the content or discourse of the text, as well as to apply the hadith in the text of the manuscript with Gracia's Hermeneutic theory about the interpretation function theory. The method used in this study is the diplomatic method and a critical or standard method that is by rewriting the contents of the text accompanied by improvements to the text limited to errors in writing. The results of this study are that the manuscripts generally contain figh books with various discussions. In terms of content analysis based on historical functions found asbabul wurud from the hadith which discusses these three things from various narrators, then the function of the meaning of the hadith is to always maintain impurity, while the implicative function is to obtain implications for modern life today to be more careful in purification.
\end{abstract}

Keywords: Manuscript, Philology, Interpretation, Gracia

\section{Pendahuluan}

Karya sastra dapat berwujud lisan maupun tulisan. Karya sastra tulisan ada yang berupa tulisan tangan dan ada pula yang berupa cetakan. Salah satu wujud karya sastra yang berupa tulisan adalah naskah atau manuskrip. Baried menjelaskan bahwa naskah merupakan tulisan tangan yang menyimpan berbagai ungkapan pikiran dan perasaan sebagai hasil budaya bangsa pada masa lampau. Naskah-naskah tersebut dituliskan di atas kertas (umumnya kertas Eropa), daluwang (kertas lokal dari daun saeh), lontar (kertas lokal dari daun lontar), bambu, dan lainnya (Fathurahman, 2015).

Naskah adalah bahan tulisan tangan dalam bentuk perangkat keras yang rill yang dapat dilihat dan diraba (Kosasih \& Supriatna, 2014). 
Adapaun menurut Darsa (2013), naskah dapat diartikan sebagai wujud kongkrit dari tulisan tangan yang di dalamnya mengandung teks, sedangkan teks sendiri merupakan muatan atau kandungan naskah yang bersifat abstrak dan hakiki atau kekal. Naskah merupakan warisan budaya nenek moyang yang perlu kita jaga dan lestarikan sebagai asset kebudayaan Nasional Indonesia. Naskah itu berisi informasi tentang hasil budaya, nilai-nilai moral pada masa lampau yang tertuang dalam teks klasik pada naskah (Saduddin, 2017). Naskah-naskah lama itu banyak tertulis dengan bahasa Melayu dengan aksara Arab, atau bahkan juga banyak yang berbahasa Arab, namun tidak semua kita mampu membaca aksara atau bahasa Arab tersebut (Erlina, 2015).

Peninggalan yang berupa naskah adalah peninggalan pikiran para pendahulu kita yang dapat dijadikan media untuk menelusuri informasi hasil budaya masa lampau. Penelusuran naskah-naskah kuno tersebut hanya bisa ditelusuri dan dikaji dengan filologi. Seorang filolog harus mempunyai bekal pengetahuan yang beraneka ragam, terutama pengetahuan bahasa yang menjadi sarana penelitiannya. Karena jangkauan studi filologi meliputi aspek kebahasaan, kesastraan, dan kebudayaan, maka pengetahuan yang luas itu mutlak diperlukan oleh seorang filolog. Seorang filolog, selain akrab dengan bahasa dan sastra, juga mengamati jalannya kebudayaan suatu bangsa.

Filologi berfungsi sebagai studi yang berupaya memahami suatu kebudayaan dan mengungkapkan nilai-nilai lama yang masih relevan dengan masa kini. Selain itu filologi juga berfungsi menyediakan suntingan teks agar dapat dipahami oleh masyarakat pada zaman tertentu, hal ini akan mempertahankan fungsi naskah secara sosial (Ibrahim, 2019).

Naskah yang akan ditelilti adalah manuskrip salinan yang diberi judul "Syarah Muqoddimah al-Imam Bafadal al-Hadramy Li al-Haitami". Pemberian judul tersebut disebabkan tidak ada judul yang tertulis di naskah salinan tersebut. Objek kajiannya adalah naskah yang membahas dua tema yaitu tentang bab air yang mensucikan dan bab jenis-jenis air yang najis. Dalam penelitian ini peneliti mengaplikasikan hadits yang ada dalam teks naskah tersebut dengan teori hermeneutika J.E. Gracia mengenai teori fungsi interpretasi yang ia bagi ke dalam tiga bagian, yaitu historical function, meaning function dan implicative function. Historical Function bertujuan untuk menciptakan kembali di benak pembaca 
kontemporer pemahaman yang dimiliki oleh pengarang teks dan audiens historis, pada fungsi ini penafsir menghadirkan pemahaman yang dapat membawa pembaca teks kontemporer seolah hadir ke masa lampau ketika teks tersebut hadir (Jorge J. E. Gracia, 1995). Dari sinilah kita dapat melihat lebih jelas mengapa interpretasi merupakan bagian integral dari pemahaman historical text untuk memahami sebuah teks. Tujannya ialah untuk menjembatani kesenjangan kontekstual, konseptual, budaya dan sebagainya yang memisahkan teks dimana ia dibaca, didengar, atau bahkan diingat. Gracia menegaskan fungsi makna bertujuan untuk menciptakan pemahaman di benak audiens kontemporer dan mengembangkan makna dari suatu teks. Terlepas dari apakah pemaknaan tersebut sama atau tidak dengan apa yang dimaksud oleh author dan audiens historis. Secara singkat implicative function dapat dipahami sebagai upaya memunculkan suatu pemahaman di benak audiens kontemporer sehingga mereka memahami implikasi dari makna teks yang ditafsirkan. Lebih jelasnya penafsir berhak mengembangkan pemahaman sebagai lanjutan dari pemahaman obyektif tersebut, sehingga teks tersebut mempunyai signifikansi dan bisa diaplikasikan sesuai untuk masa dan tempat di mana penafsiran itu dilakukan.

Dalam penelitian ini, bahwa naskah "Syarah Muqoddimah al-Imam Bafadal al-Hadramy Li al-Haitami", termasuk dalam kategori naskah tunggal. Hal tersebut disimpulkan setelah melakukan penelusuran ke berbagai perpustakaan, seperti perpustakaan Sonobudoyo, UPT UIN Sunan Kalijaga, perpustakaan UGM, dan perpustakaan UNY, naskah tersebut belum pernah ada yang mengkaji sama sekali. Peneliti mengambil kesimpulan, bahwa para filolog belum pernah ada yang meneliti naskah ini, sehingga naskah ini layak untuk diteliti secara mendalam dari segi bunyi teks maupun isi teks.

\section{Metode}

Metode yang digunakan dalam penelitian ini adalah metode diplomatis yakni dengan menulis kembali isi teks tanpa ada penambahan dan pengurangan apapun, namun metode ini kurang membantu pembaca dalam memahami isi teks. Kemudian peneliti juga mengunakan metode kritis atau standar yaitu dengan menulis kembali isi teks dengan disertai perbaikan terhadap teks terbatas pada kesalahan-kesalahan dalam 
penulisan. Semua perbaikan ini, kalaupun ada, akan dilakukan dengan cara memberi catatan agar teks terjaga keasliannya.

\section{Hasil dan Pembahasan}

\subsection{Inventarisasi Naskah}

Naskah tersebut didapatkan dari seorang dosen Fak. Adab dan Ilmu Budaya UIN Sunan Kalijaga Yogyakarta, yaitu Dr. Habib Abdul Syakur. Ia tinggal di Pondok Pesantren Al-Imdad Bantul Yogyakarta. Naskah ini merupakan salah satu naskah yang dititipkan oleh seorang sahabat dari Purworejo Jawa Tengah sebagai warisan turun temurun dari nenek moyangnya. Naskah ini dititipkan kepada Dr. Habib Abdul Syakur dengan tujuan agar naskah tersebut tetap terjaga dari kerusakan dan kerapuhan kertas yang sudah. Naskah tersebut merupakan naskah tunggal, karena setelah menelusuri ke berbagai perpustakaan yang berhubungan dengan naskah-naskah, seperti yang kami sebutkan sebelumnya. Hasil dari penelusuran, kami tidak menemukan naskah yang serupa atau sudah ada peneliti yang menelitinya. Untuk itu, peneliti menyatakan bahwa naskah ini adalah naskah tunggal

\subsection{Deskripsi Naskah}

Naskah ini berukuran $34 \times 21 \mathrm{~cm}$ dengan ketebalan 4,5 cm. Margin halaman dalam naskah berukuran bawah $8 \mathrm{~cm}$ dan kiri kanan $7 \mathrm{~cm}$. Kuras naskah terdiri dari 13 kuras dengan jumlah 16 halaman per kurasnya. Setiap baris dalam 1 halaman berjumlah 13 baris. Kertas yang digunakan pada naskah ini adalah kertas Eropa yang cukup tebal, terlihat bayangan garis halus, bayangan garis tebal, dan sebagian cap air pada margin tengah.

Terdapat tiga cap air pada naskah dengan kertas yang berbeda-beda. Salah satunya ada tulisan W....P...koek dan A D T. Pada kertas tergmbar macan membawa pedang dalam lingkaran bermahkota dan terdapat tulisan PRO PATRIA EENDRAGT MAAKT MAGT di sekitarnya. Setelah dilakukan pengecekan pada katalog watermark, ditemukan bahwa kertas tersebut diproduksi di Belanda antara tahun 1864-1878. Sehingga dapat diperkirakan usia naskah sekitar 135 tahun dan sampai di Indonesia pada tahun 1883. 
Bentuk tulisan naskahnya Arab dengan bahasa yang digunakan bahasa Arab Fushah. Penjilidan menggunakan kayu dan penjahitan menggunakan benang kasur. Adapun alat tulis yang digunakan peneliti naskah adalah pena dari bulu angsa dengan tinta berwarna hitam dan rubrikasi berwarna merah. Tinta warna merah digunakan untuk menulis matan teks sedangkan tinta hitam untuk syarah-nya. Tulisan masih dapat dibaca namun kondisi kertas sudah banyak yang bolong dimakan rayap dan penjilidan kuras sudah banyak yang terlepas.

Kutipan awal teks sebagai berikut:

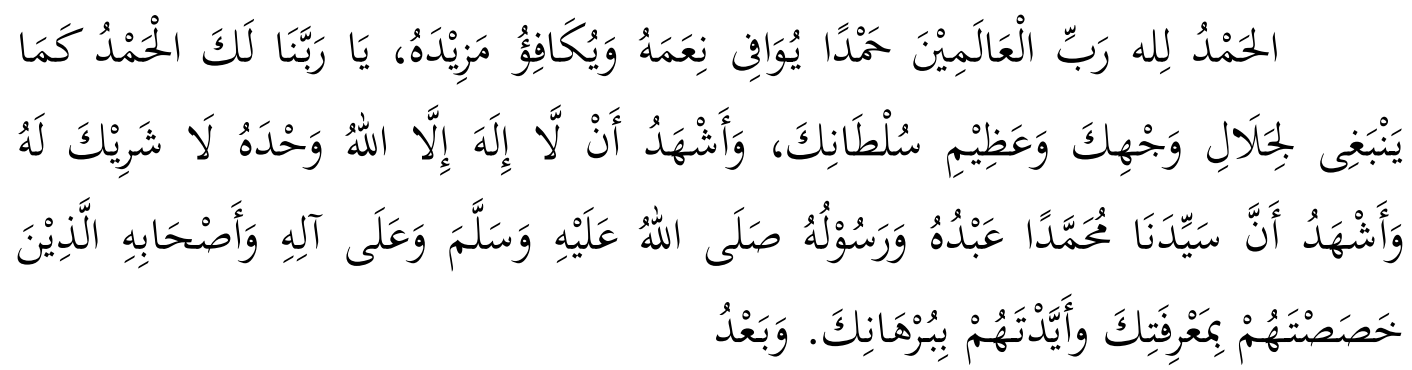

Kutipan akhir teks sebagai berikut:

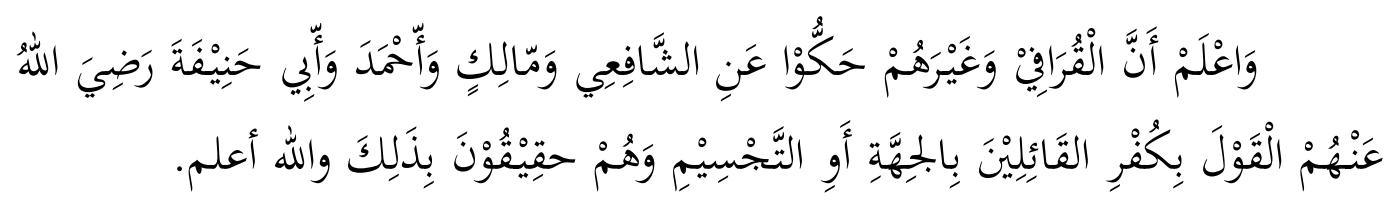

\subsection{Ringkasan Isi Naskah}

Setelah melakukan penyuntingan dan penerjemahan, secara umum naskah tersebut berisi tentang masalah fiqih. Dari sekian fasal yang ada, peneliti mengambil dua fasal untuk diteliti yaitu fasal air musta'mal dan jenis-jenis air yang menajiskan. Dalam kedua fasal tersebut secara umum menjelaskan tentang kriteria air yang dapat digunakan untuk mensucikan dan uang menyebabkan najis. Tidak sah bersuci dengan air musta'mal, karena ada beberapa jenis air musta'mal yaitu (a) air yang digunakan untuk menghilangkan hadas, walaupun berupa hadasnya anak kecil yang belum tamyis. Hal ini berdasar pada syahnya thawaf dengan syarat suci dari hadas, pendapat ini adalah pendapat yang kuat, (b) air yang digunakan untuk menghilangkan kotoran walaupun kotoran tersebut dima'fu (dispensasi), (c) air yang digunakan oleh daimul hadas (orang yang selalu hadas karena suatu penyakit), namun kalangan ulama Hanafi membolehkannya, (d) air yang digunakan untuk memandikan mayat, (e) 
air yang digunakan orang kafir Kitabiy untuk bersuci dari haid dan nifas, (f) air yang digunakan seorang perempuan gila ketika suami memandikannya. Hal itu dikarenakan, air yang digunakan bisa menghilangkan larangan untuk salat. Sehingga larangan tersebut menyebabkan air menjadi musta'mal. Begitu juga dengan Air yang sedikit (kurang dari dua qullah), dan benda cair (walaupun lebih dua qullah) menjadi najis apabila terkena barang najis, walaupun airnya tidak berubah. Hal ini berdasar pada pemahaman hadis Nabi saw: "Apabila air sampai dua qullah maka ia tidak terbebani kotoran (najis)", dari hadis ini bisa dipahami bila air tidak sampai dua qullah maka ia akan menanggung najis atau berdampak najis.

Satu hal yang menarik bagi peneliti, dalam muqadimah, pengarang menyampaikan suatu pengajaran bagi kita bahwa sebenarnya kita tidak diharuskan atau diwajibkan mempelajari ini semua, ada perbedaan antara kewajiban individu dan mana kewajiban sosial. Namun, jika kita semua membutuhkan keilmuan itu dan menjadi kebutuhan individu, maka kita menjadi wajib mempelajarinya. Jadi secara tidak langsung dengan bahasa yang halus, pengarang menyeru kepada kita untuk mempelajari kitab ini. Karena pada suatu saat kita pasti memerlukannya.

\subsection{Suntingan Air Mensucikan dan Menajiskan pada Naskah}

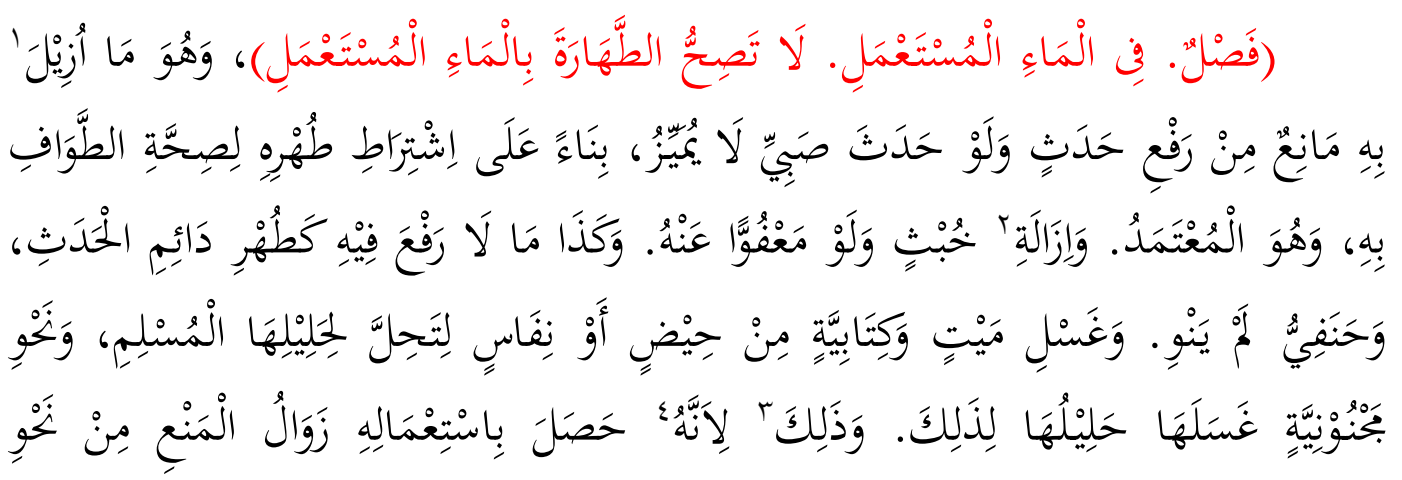

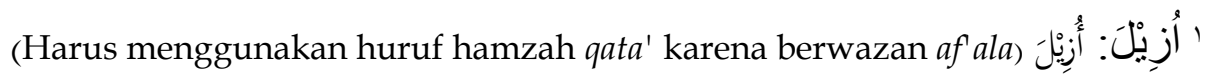

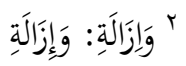

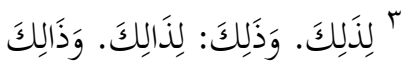

(karena hamza huruf asal) 


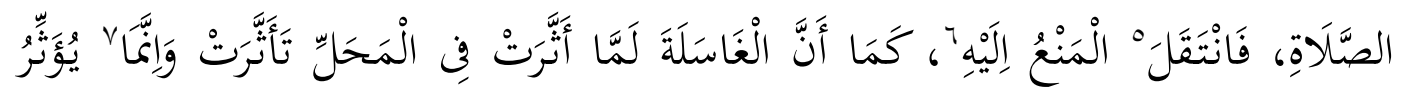

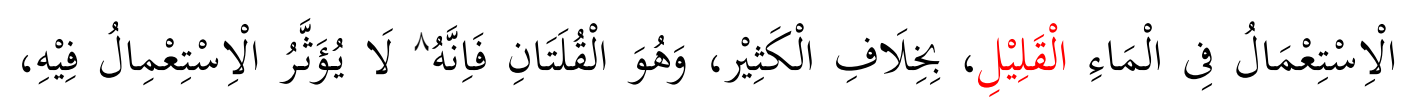

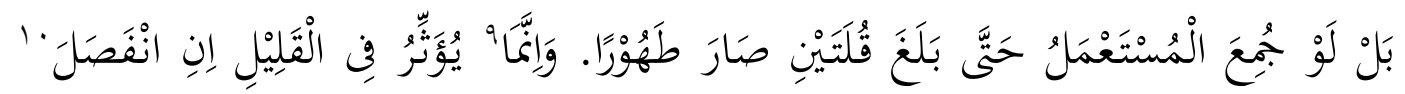

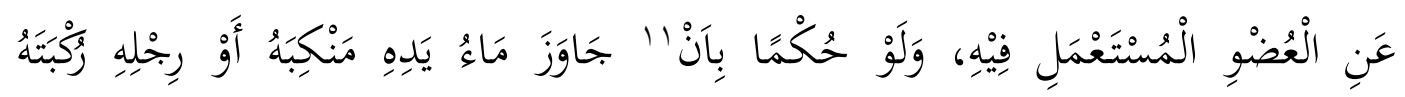

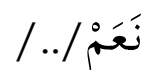

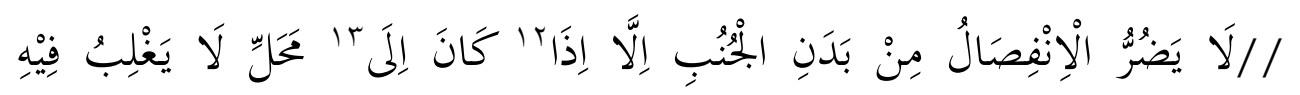

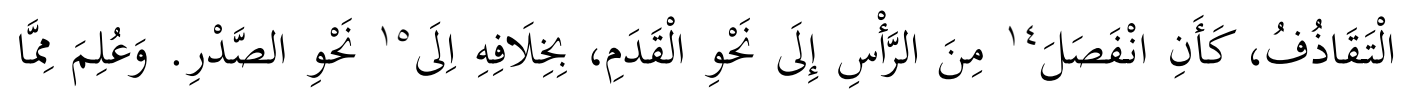

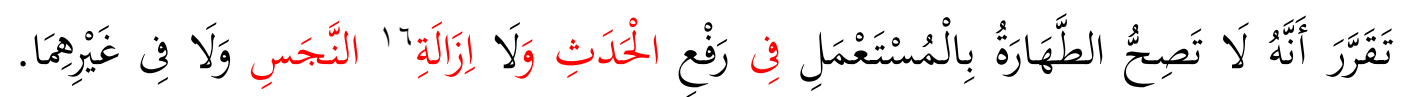

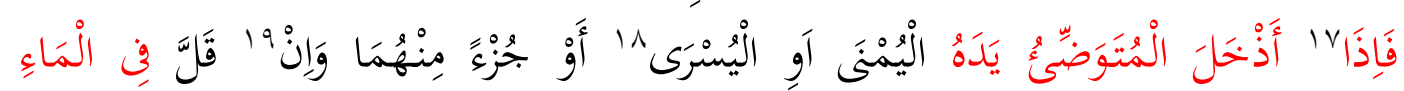

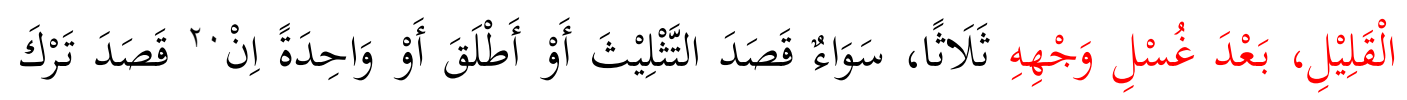

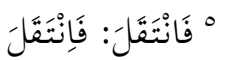

"إليَّ: إلَّهُ:

罗

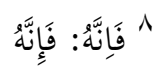

罗

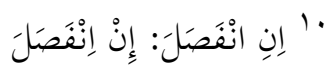

"l

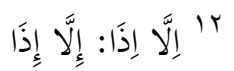

"إل إلى

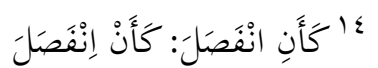

إلى

罗"

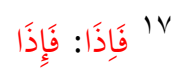

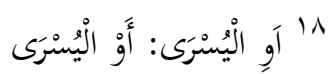

19 19

ب. 


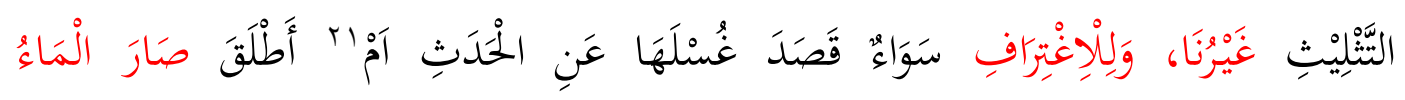

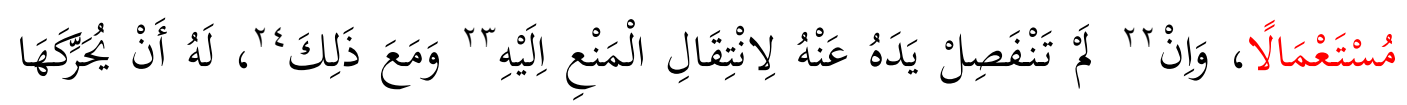

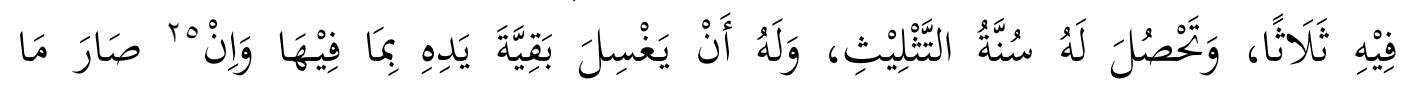

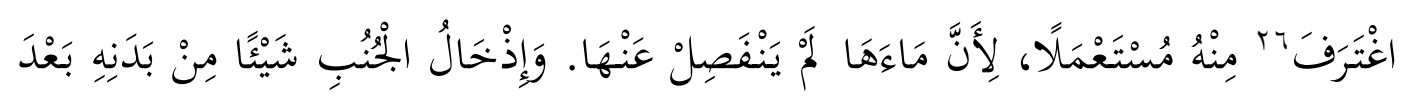

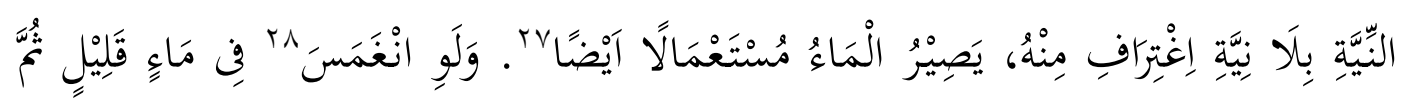

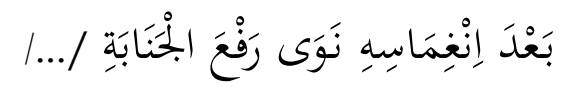

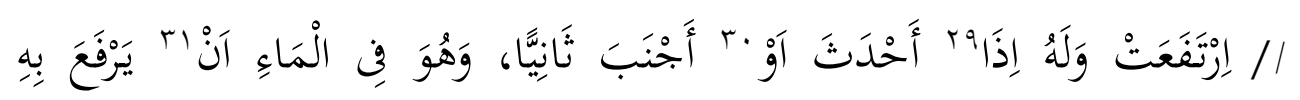

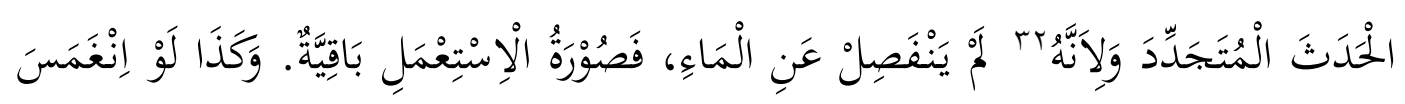

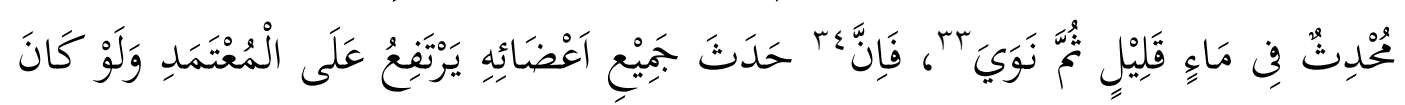

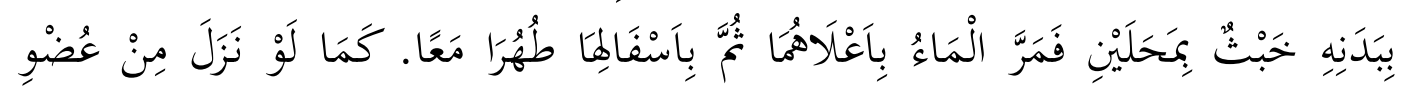

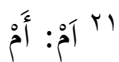

$$
\begin{aligned}
& \text { rr } \\
& \text { "rr }
\end{aligned}
$$

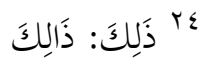

$$
\begin{aligned}
& \text { مَ }
\end{aligned}
$$

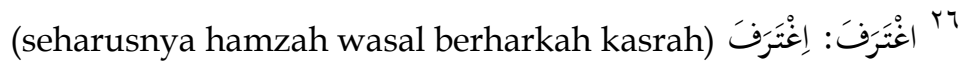

$$
\begin{aligned}
& \text { أيْضًا: أََْْضًا }
\end{aligned}
$$

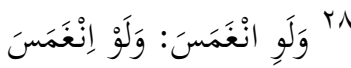

$$
\begin{aligned}
& \text { 罗 }
\end{aligned}
$$

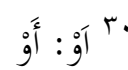

$$
\begin{aligned}
& \text { 象 } \\
& \text { لrr }
\end{aligned}
$$

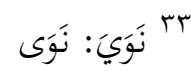

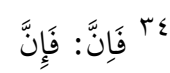




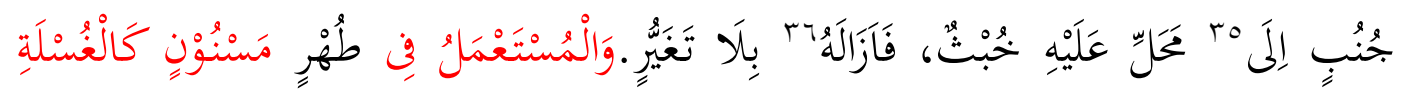

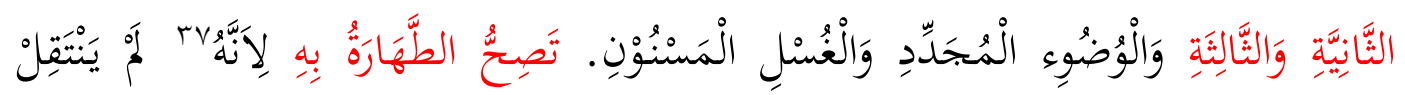

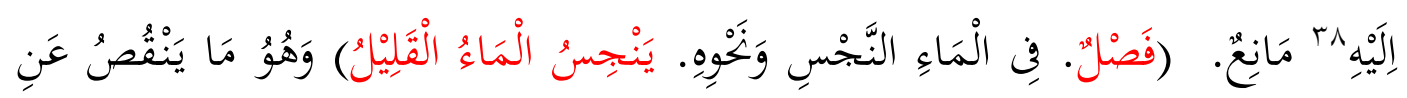

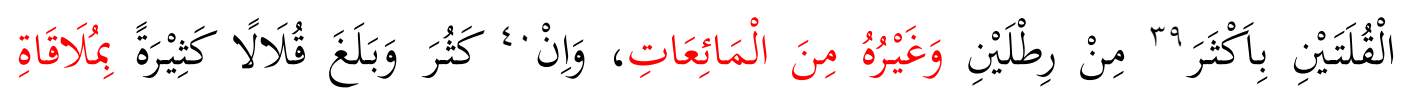

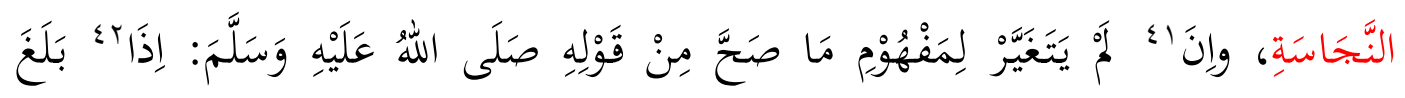

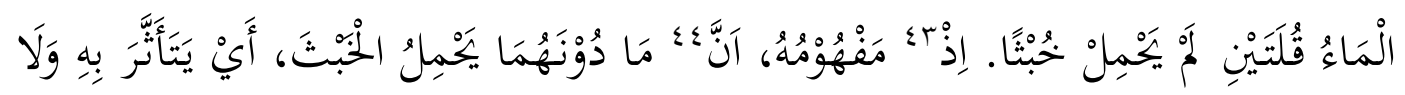

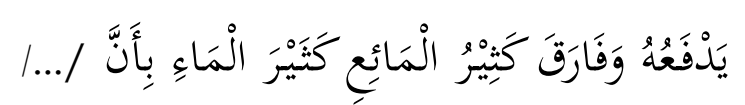

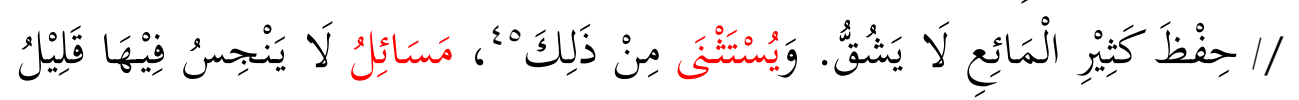

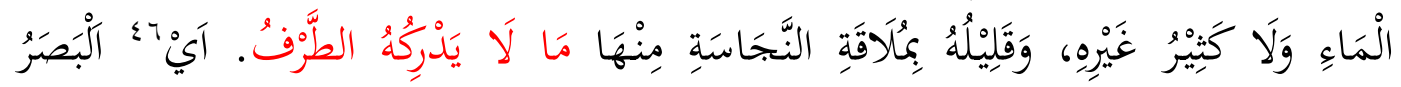

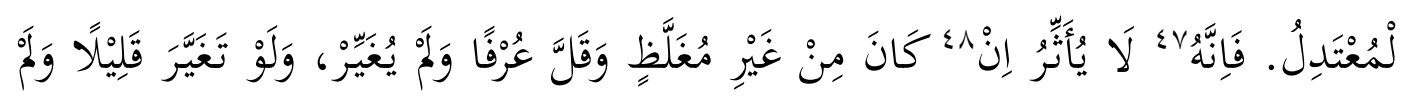

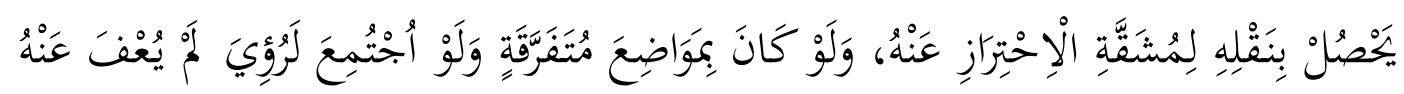

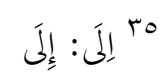

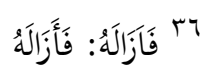

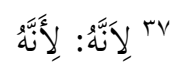

$$
\begin{aligned}
& \text { ^r }
\end{aligned}
$$

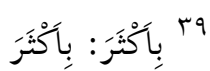

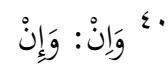

$$
\begin{aligned}
& \text { اء وإِنَ: وإِنْ } \\
& \text { r }
\end{aligned}
$$

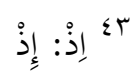

$$
\begin{aligned}
& \text { ؛ ؛ } \\
& \text { هـ ذَلِكَ: ذَلِكَ } \\
& \text { بـ آَيْ: أَيْ }
\end{aligned}
$$

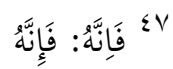

$$
\begin{aligned}
& \text { ^^ إِنْ: إِنْ }
\end{aligned}
$$




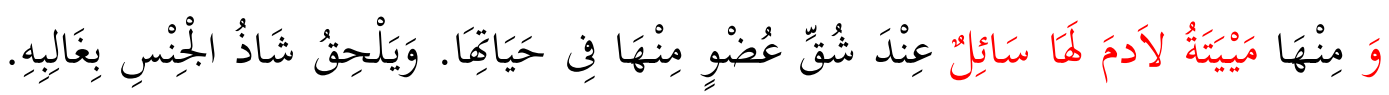

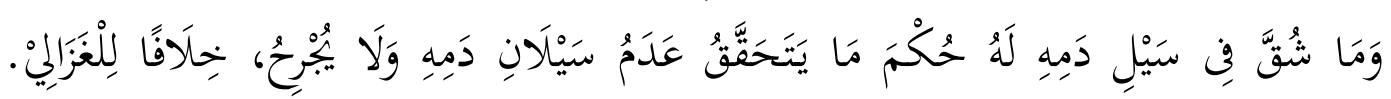

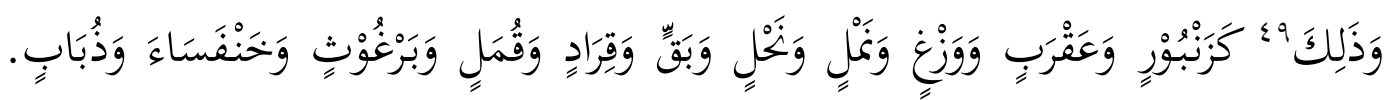

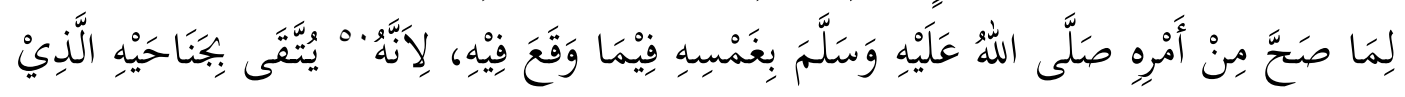

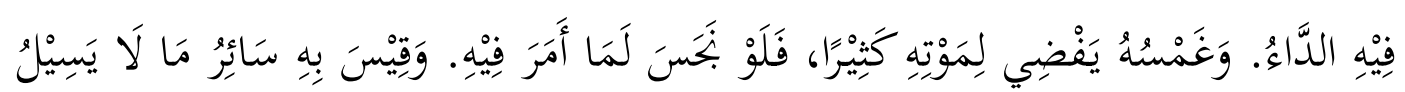

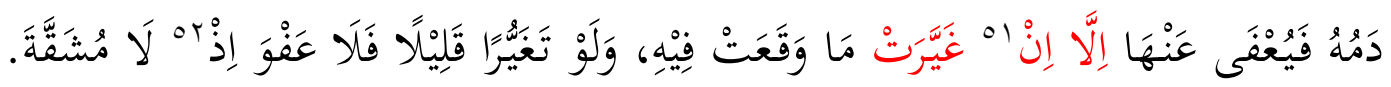

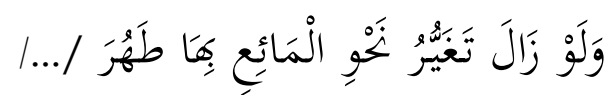

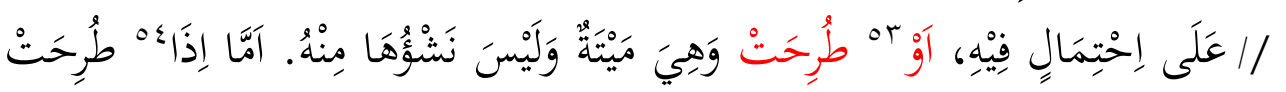

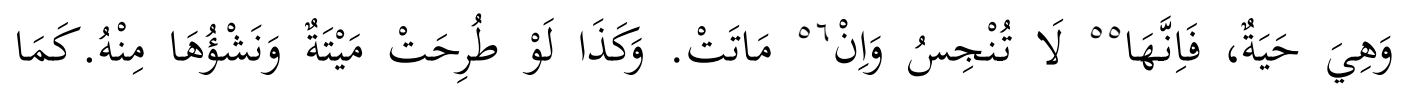

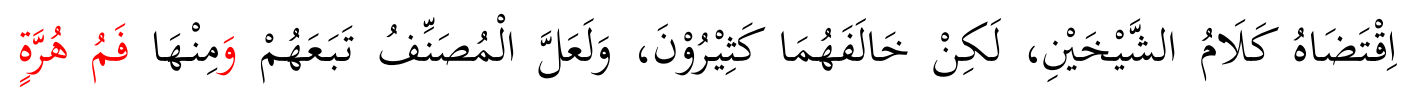

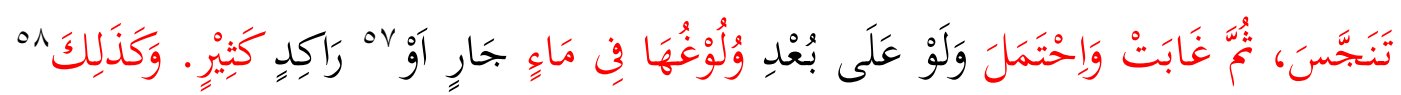

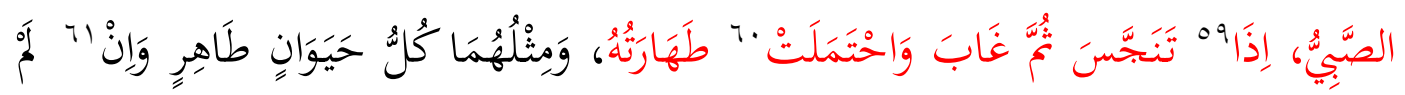

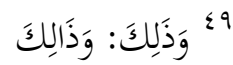

$$
\begin{aligned}
& \text { • }
\end{aligned}
$$

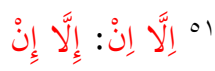

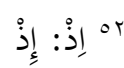

$$
\begin{aligned}
& \text { أو أو }
\end{aligned}
$$

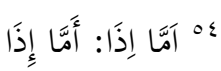

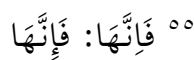

$$
\begin{aligned}
& \text { هُه وَإِنْ: وَإِنْ }
\end{aligned}
$$

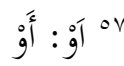

$$
\begin{aligned}
& \text { هـ } \\
& \text { ه9 }
\end{aligned}
$$

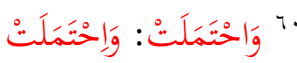

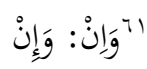




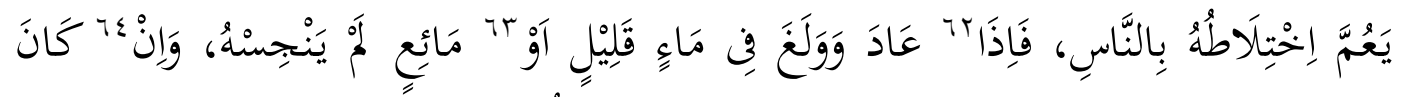

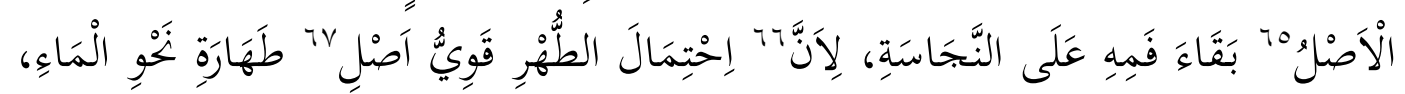

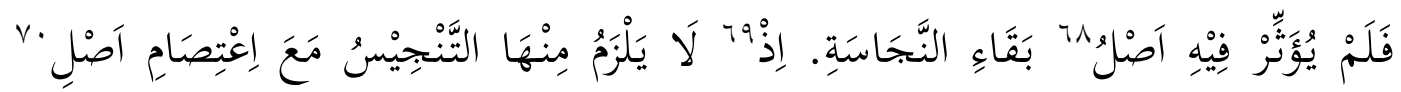

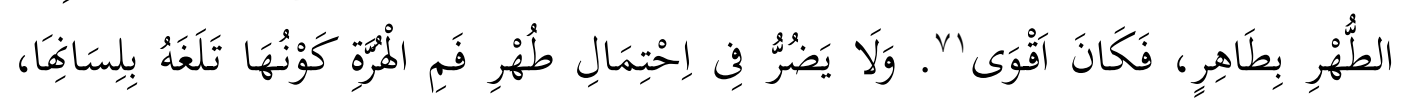

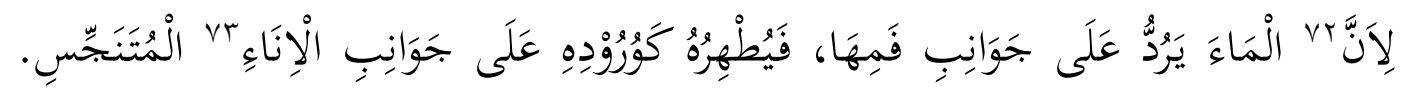

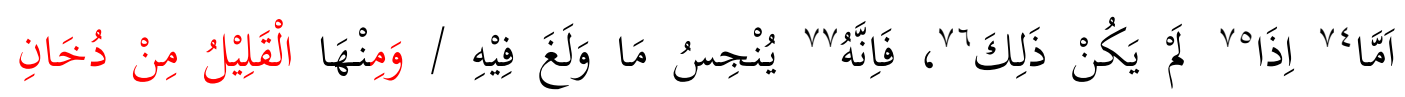

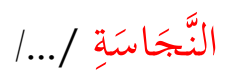

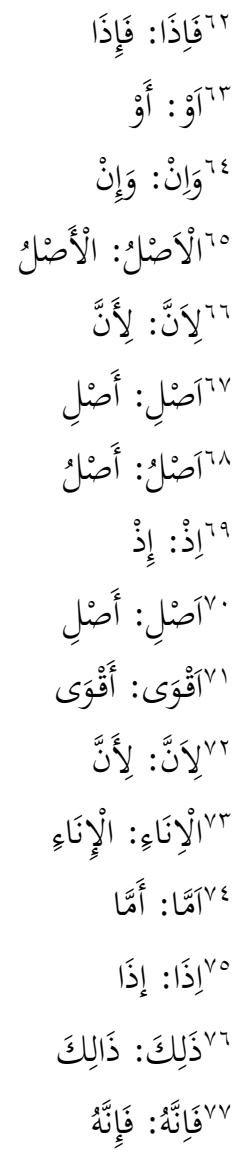




\subsection{Transliterasi dan Terjemah Naskah}

\section{Trasliterasi}

Faṣlun. fi al-māi al-musta'mali là taṣihhu at-țahāratu bi al-māi almusta'mali, wa huwa mā uzila bihi māni'un min raf'in hadasin wa lau hadaśa sabiyin lā yumayyizu, bināan 'ala isytirati tuhrihi lisiḥhati al-țawāfi bihi, wa huwa al-mu'tamādu. wa izālati khubsin wa lau ma'fuwan 'anhu. wa każa mā lā raf'a fỉhi katuhri dāimi al-hadaśi. wa hanafiyyu lam yanwi. wa gasli mayyitin wa kitābiyyatin min hayșin au nifāsin litahilla lihaliliha al-muslimi, wa nạ̣wi majnūnatin gassalahā haliliha liżàlika. wa żālika lannahu hașala bisti'māllihi zawālu al-man'i min nahwi al-șalāti. fantaqala al-man'u ilayhi, kamā anna al-gasālata lammā as̉sarat fi almahalli taas̄sarat $\mathrm{Wa}$ innamā yuas̄siru al-isti'mālu fi al-māi al-qalili, bi khilafi al-kasīiri, wa huwa al-qulatāni. fainnahu lā yuašsiru al-isti'mālu fihi, bal lau jumi'a al-musta'malu hatta balaga qulatayni șāra țahūran. wa innamā yuašsiru fi al-qatili in infașala 'an al'udwi al-musta'mali fîhi, wa lau hukman bian jāwaza māu yadihi mankibahu au rijlihi rukbatahu $\mathrm{Na}^{\prime} \mathrm{am} /$

\section{Terjemahan}

Fasal tentang air musta'mal. Tidak sah bersuci dengan air musta'mal. Jenis air musta'mal adalah (a) air yang digunakan untuk menghilangkan hadas, walaupun berupa hadasnya anak kecil yang belum tamyis. Hal ini berdasar pada syahnya thawaf dengan syarat suci dari hadas, pendapat ini adalah pendapat yang kuat; (b) air yang digunakan untuk menghilangkan kotoran walaupun kotoran tersebut dima'fu (dispensasi) (c) air yang digunakan oleh daimul hadas (orang yang selalu hadas karena suatu penyakit) namun kalangan ulama hanafi membolehkannya (d) air yang digunakan umtuk memandikan mayat, (e) air yang digunakan orang kafir kitabiy untuk bersuci dari haid dan nifas; (f) air yang digunakan seorang perempuan gila ketika suami memandikannya. Hal itu dikarenakan, air yang digunakan bisa menghilangkan larangan untuk salat. Sehingga larangan tersebut menyebabkan air menjadi musta'mal, seperti seorang yang lagi mandi percikan air mengenai badan maka badan tersebut menjadi musta'mal, dengan sarat air yang dikenai percikan masih sedikit, namun bila air yang dikenai percikan banyak (sekitar dua qullah) maka air tersebut tidak musta'mal. Bahkan bila air 
musta'mal dikumpulkan sampai dua qulla maka air tersebut berubah menjadi suci dan mensucikan (tahur). Hanya saja air yang sedikit tersebut menjadi musta'mal bila terkena percikan air basuhan dari anggota tubuh yang musta'mal. Walaupun najis hukman, seperti air yang ditangan mengalir ke pundak atau kaki, atau dari kaki ke tumitnya, ya /

/ / Là yaḍurru al-infiṣālu min badani al-junubi, illā iḍa kāna ila mahallin lā yaglibu fỉhi at-taqāżufu, kain infașala min al-ra'si ila naḥwi al-qadami, bikhilafihi ila nạ̣wi aṣ-ṣadri. wa 'ulima mimmā taqarrara annahu lā tasiḥ̣u altahāratu bi al-musta'mali fi rafi alḥadaśi wa lā izālati al-najsi wa là fi gayrahimā. fa iżà adkhala almutawaḍdi'u yadahu al-yumna au alyusra au juzan minhumā wa in qalla fi al-māi al-qāili, ba'da gasli wajhihi salāsan, sawāun qasada al-taślìsa au aṭlaqa au wāhidatan in qaṣada tarka attaślisi gayranā, wa lil-igtirāfi sawāun qașada gaslahā an al-ḥadasi am aṭlaqa șāra al-mā'u musta'mālan, wa in lam tanfașil yadahu 'anhu liintiqāli al-man'i ilayhi wa ma'a żālika, lahu an yuharrikuhā fỉhi śalàsan. Wa tạ̣ṣulu lahu sunnatu al-tasंlisi, wa lahu an yagsila baqiyyata yadihi bima fîha wa in șāra mā igtarafa minhu musta'mālan, lianna māahā lam yanfașil 'anhā. wa idkhālu al-junubi syaian min yadihi ba'da al-niyyati bilā niyati igtirāfi minhu, yașīu al-māu musta'mālan ayḍan. wa lau ingamasa fi māin qalílin, summa ba'da ingimāsihi nawā raf'a aljinābati/
// Akan tetapi, tidak masalah percikan dari air badan orang yang junub kecuali jika mengenai badan yang airnya tidak deras, seperti air dikepala mengalir ke kaki, sebaliknya jika air tersebut mengalir ke dada. Dari pernyataan diatas dapat disimpulkan bahwa tidak sah bersuci dengan air musta'mal untuk bersuci dari hadas atau menghilangkan najis atau selain keduanya. Apabilla orang yang berwudu' memasukkan tangan kanan, tangan kiri atau bagian anggota tangan ke dalam air yang sedikit setelah membasuh mukanya tiga kali dengan maksud tiga-tiga atau tidak, atau sekali dengan maksud meninggalkan tiga-tiga menurut pendapat selain kami (madhab syafi'iy), atau mencelupkannya dengan maksud untuk menghilangkan hadas atau tidak maka air terrsebut menjadi musta'mal walaupun tangannya masih didalam air karena berpindahnya mani' ke dalam air tersebut dalam keadaan demikian 
ia menggerakkan tangannya tiga kali. Membasuh tiga kali menjadi sunnah jika orang tersebut membasuh anggota tangan yang belum terkena basuhan, walaupun anggota badan yang dicelupkan ke dalam air tersebut menjadi musta'mal disebabkan percikan air yang ada di anggota tangan. Begitu juga air menjadi musta'mal jika orang yang sedang junub memasukkan bagian anggota badannya dengan niat menghilangkan hadas atau iseng. Jika seseorang mencelupkan kedalam air setelah mencelupkan kedalam air niat untuk menghilangkan hadas, maka ia telah suci dari hadas/

//Irtafá'at. wa lahu iżā ahdaśa au ajnaba sāniyyan, wa huwa fi al-māi an yarfa'a bihi al-hadaśa al-mutajaddida liannahu lam yanfașil 'an al-māI, fașuwratu al-isti'māli bāqiyyatun. Wa każā lau ingamasa muhdišun fi māin qalilin summa nawa, fainna hadaśa jami'i a'ḍ̄ihi yartafi'u ala al-mu'tamadi /Wa lau kāna badanihi khabśn bimahalayni, famarra al-māu bi a'lāhuma summa biasfālihima țahurā ma'an. Kamā lau nazala min 'uḍwi junubin ila mahalin alayhi khabṡun, faazālahu bilā tagayyurin. Wa al-musta'malu fĩ țuhrin masnūnin ka al-gaslati al-s̄aniyyati wa al-sālisàti wa al-wựui al-mujaddidi wa al-gasli al-masnūni taṣihḥu al-țahāratu bihi liannahu lam yantaqil ilayhi māni'un. Faṣlun. fi al-māi al-najsi wa nahwihi. yanjusu al-māu al-qalilu, wa huwa mā yanquṣu an al-qulatayni biakśara min ritlayni wa gayruhu min almāi'àti. wa in kaśura wa balaga qulālan kasīratan bimulāqāti al-najāsati, wa in
//Seandainya dia hadas atau junub keduakalinya dan dia masih berada dalam air untuk menghilangkan hadas yang baru, maka air tetap musta'mal. Begitu pula jika orang yang sedang hadas menceburkan semua anggota badannya ke dalam air kemudian berniat untuk menghilangkan hadas maka, maka ia sudah tidak hadas lagi menurut pendapat yang mu'tamat (kuat) / Jika di badannya ada kotoran di dua tempat, kemudian ia air mengalir dari tempat tinggi ke tempat rendah maka kedua tempat tersebut menjadi suci. Hal ini Seperti air yang mengalir dri angota badan orang yang junub ke tempat yang ada kotorannya kemudian kotoran tersebut bersih dan air tidak berubah warna bau. Sah 
lam yatagayyar limafhumi mā șahiha min qawlihi salla allāhu 'alayhi wa sallama. iża balaga al-māu qulatayni lam yahmil khabsan. iż mafhumuhu, anna mā duwnahumā yạ̣milu al-khabśa, ay yataaşsaru bihi wa lā yadfa'uhu wa färaqa kasìru al-māiy'i kaśiru al-māI, bianna/

\section{//Hifụa kasīiri al-māiy'i lā} yasyuqqu. wa yustaśna min żālika, masāilu lā yanjisu fiyhā qaTilu al-māi wa là kas̄iru gayrihi, wa qaßiluhu bimulāqāti al-najāsati. minhā mā lā yudrikuhu altarfu. ay al-bașaru al-mu'tadilu. fainnahu lā yuaṡsiru in kāna min gayri mugallaḍin wa qalla 'urfan wa lam yugayyir, wa lau tagayyara qaiilan wa lam yahșul bi nqlihi li musyaqqati al-ihtirāazi 'anhu, wa lau kāna bi mawādi'a mutafarriqatin wa lau ujtumi'a laruiya lam yu'fa 'anhu, Wa minhā maytatun lā dama lahā sāilun inda syuqqi 'udwin minhā fì hayātihā. wa yulhiqu syāżu al-jinsi bi gālibihi. wa mā syuqqa fí sayli damihi lahu hukmu mā yatahaqqaqu 'adamu saylāni damihi, wa lā yujrahu, khilāfan lilghazaliy. wa hukumnya bersuci menggunakan air musta'mal dari taharah yg sunnah seperti air basuhan wuduk yang kedua dan ketiga, tajdidul wudu', dan mandi yang disunnahkan; karena mani' (hal yang mencegah kesucian air) tidak pindah ke air tersebut. fasal. Air dan sejenisnya yang najis. Air yang sedikit (kurang dari dua qullah) dan benda cair (walaupun lebih dua qullah) menjadi najis apabila terkena barang najis, walaupun airnya tidak berubah. Hal ini berdasar pada pemahaman hadis Nabi saw: "apabila air sampai dua qullah maka ia tidak terbebani kotoran (najis)", dari hadis ini bisa dipahami bila air tidak sampai dua qullah maka ia akan menanggung najis atau berdampak najis dan tidak bisa menghindarinya. Benda cair berbeda dengan air yang banyak/

//menjaga air yang banyak tidak sulit. Ada pengecualian dari persoalan tersebut, air yang sedikit atau banda cair yang banyak maupun yang sedikit tidak menjadi najis jika terkena najis yang tidak kelihatan dzatnya oleh mata. Najis tersebut bukan najis mughalladah, sedikit dan tidak mengubah air. Jika air tersebut berubah walaupun sedikit dan tidak berhasil membuang najis tersebut karena sulit untuk menjaganya dan di tempat yang berpencar dan seandainya dikumpulkan pasti akan kelihatan najis tersebut maka air tersebut 
żālika kazanbūri wa 'aqrabin wa wazgin wa namlin wa naḥlin wa baqqin wa qirādin wa qumālin wa bargūisin wa khanfasāa wa żubābin. limā șahha min amri șalla al-lāhu alayhi wa sallama bighmsihi fīmā wa qa'a fíhi. liannahu yuttaqa bijanāhayhi allażi fỉhi al-dā'u. wa gamsuhu yaqdi limautihi kasīran. fa law najasa lamā amara fîhi. wa qisa bihi sāiru mā lā yasīlu damuhu. fayu'fa 'anhā illā in gayyarat mā waqa'at fihi, wa lau tagayyaran qalilan falà afwa iż là musyaqqata. wa lau zāla tagayyuru naḥwi al-māi'i bihā țahura/ menjadi najis. Bangkai hewan yang darahnya tidak mengalir ketika anggota tubuhnya terpotong sewaktu masih hidup. Hewan yang dipersoalkan jenisnya, apakah darahnya mengalir atau tidak maka dianggap/ dihukumi darahnya tidak mengalir, dan tidak butuh pembuktian (seperti pembedahan) seperti yang dikatakan Imam Ghazali. Seperti: tabuhan (kumbang besar), kalajengking, wazwin, semut, lebah, kutu, kutu binatang, kutu, kutu, kumbang, dan lalat. Hal ini berdasar pada hadis Nabi saw; yang menyuruhnya untuk menenggelamkannya ke dalam air tersebut yang dihinggapinya, karena salah satu kedua sayapnya ada obat, dengan menenggelamkannya menyebabkan hewan tersebut akan mati. Anadaikan hewan tersebut najis niscaya Nabi tidak menyuruh untuk menenggelamkannya. Dan semua hewan yang darahnya tidak mengalir dianalogkannya. Maka hewan tersebut tidak menyebabkan najis dengan ketentuan air tersebut tidak berubah walau sedikitpun, jika airnya berubah maka airnya najis karena tidak sulit untuk menjaganya, dan jika air tersebut perubahanya hilang (air tersebut kembali ke warna asalnya) maka air tersebut menjadi suci kembali. Seperti menuangkan air yang 
lain/

/ /'ala ihtimālin fîhi, au țurihat wa hiya maytatun wa laysa nasyuhā minhu. Ammā iżà turihạat wa hiya hayatun, fainnahā la tunjisu wa in mātat. wa każā lau turihat maytatun wa nasyuhā minhu. kamā iqtạ̣ahu kalāmu al-syaikhāini, lakin khālafahumā kaśiyrūna, wa la'alla al-muṣannifu taba'ahum. Wa minhā famu hurratin tanajjasa, summa gābat wa ihtamala wa lau 'ala bu'din wulūguhā fì māin jārrin au rākidin kas̄irin. Wa każālika al-ṣabiyyu, iżā tanajjasa summa gāba wa ihtamalat tahāratuhu, wa mislahumā kullu hayawānin țāhirin wa in lam ya'umma ikhṭilātuhu bi al-nāsi faiżā 'àda wa walaga fî māin qalilin au māi'in lam yunjisu. Wa in kāna al-aṣlu baqāa famihiala al-najāsati, lianna ihtimāla alțuhri qawiyyu aṣli tahārati nahwi al-māI, falam yuaṡsir fỉhi aṣlu baqāi al-najāsati. iż lā yalzamu minhā al-tanjisu ma'a i'tișāmi aṣli al-ṭuhri bi țāhirin, fa kāna aqwa. walā yaḍurru fí ihtimāli țuhri fahmial-hurrati kaunuhā talagahu bilisānihā, lianna al-māa yaruddu ala jawānibi famiha, fayuthiruhu kawurūdihi ala jawānibi al-ināi almutanajjisi. ammā iżà lam yumkin żālika fainnahu yunjisu mā walaga fỉhi wa minhā al-qalilu min dukhani alnajāsati/. //ke dalam air tersebut atau membuang bangkai tersebut dan bangkai tersebut masih utuh. Adapun bila hewan tersebut di lempar ke dalam air dalam keadaan masih hidup maka hewan tersebut tidak najis. Begitu juga bila dimasukkan kedalam air hewan tersebut dalam keadaan mati dan tidak utuh lagi maka hewan tersebut tidak najis sebagaimana yang dikatakan syaikhani (Nawawi dan Rofi'i) namun mayoritas ulama' menolak pendapatnya. Namun Musannif (pengarang) mengikuti pendapat mayoritas ulama'. Persoalan yang lain adalah masalah mulut kucing yang najis namun tidak tampak najisnya dan masih kelihatan najis kemudian ia memasukkan mulutnya ke dalam air yang mengalir atau diam, juga persoalan anak kecil yang terkena najis namun tidak tampak dan dianggap masih suci dan seperti keduanya semua hewan yang suci walaupun pada umumnya jarang berbaur dengan manusia maka apabila ia mengulangi atau mencelupkan kedalam air lagi, baik air itu sedikit atau banyak maka air tersebut tidak najis, walaupun pada mulanya mulut kucing masih ada najis. Ini dikarenakan kecendrungan suci lebih kuat dari sucinya air, maka sisa najis tidak mempengaruhinya, karena tidak pasti menajiskannya dan kuatnya asal suci dengan 
perkara suci. Maka perkara yang suci lebih kuat. Begitu juga tidak mudarat mulut kucing yang suci dan lidahnya dicelupkan ke dalam air, karena air terletak di pinggir mulutnya sebagaimana air yang berada di pinggir wadah yang najis. Namun bila tidak demikian maka air tersebut najis. Persoalan yang lain adalah asap yang berasal dari benda yang najis walaupun sedikit/.

\subsection{Air Musta'mal dan Ghair Musta'mal}

Dalam naskah tersebut, khususnya pada dua fasal yang peneliti kaji, terdapat hadits Nabi yang menarik untuk di analisis melalui teori fungsi teks J. E. Gracia. Ada beberapa poin penting yang dapat di analisis dalam teks naskah tersebut, yaitu dikaitkan dengan hadits mengenai air yang tidak menyebabkan najis, pertama, karena kadar airnya dua qullah, kedua, karena air yang telah dijilati oleh kucing dan ketiga, karena air bekas mandi junub.

Adapun hadits Nabi S.a.w yang terdapat dalam teks naskah tersebut mengenai penjelasan air dua qullah, yaitu berbunyi : "apabila air sampai dua qullah maka ia tidak terbebani kotoran (najis)", selain itu ada juga pembahasan dari air yang dijilati kucing juga tidak menjadi najis, begitu pula air bekas mandi junub tidak menajiskan. Setelah peneliti telusuri melalui CD-ROM Mausu'ah al-Hadits al-Syarif al-Kutub al-Tis'ah, Global Islamic Software, 1997, ditemukan banyak sekali hadits Nabi yang menjelaskan hal tersebut. Namun dalam penelitian ini peneliti hanya mengambil satu hadits dari tiga periwayat untuk dijadikan acuan dalam analisis, yaitu hadits tentang air dua qullah, air yang dijilat kucing, dan air bekas mandi junub.

Adapun bunyi haditsnya sebagai berikut :

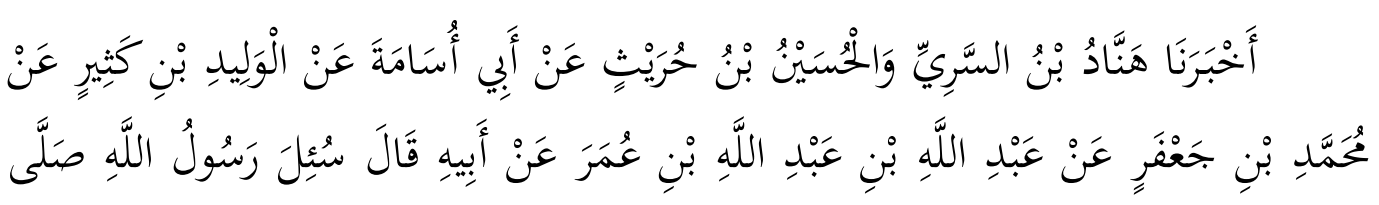




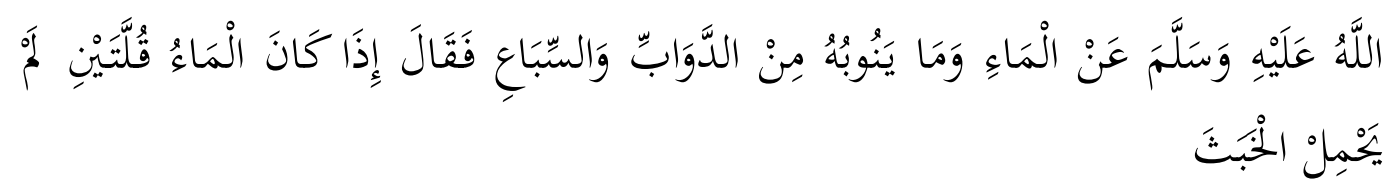

Artinya: Telah mengabarkan kepada kami Hannad bin As-Sariy dan Husain bin Huraits dari Abu Usamah dari Al Walid bin Katsir dari Muhammad bin Ja'far dari Abdullah bin Abdullah bin Umar dari Ayahnya berkata; Rasulullah shallallahu 'alaihi wasallam pernah ditanya tentang air dan (air) yang diminum oleh hewan ternak dan binatang buas berulang kali? Beliau shallallahu 'alaihi wasallam lalu menjawab, "Bila air itu lebih dari dua qulah maka tidak mengandung najis." (Hadits Riwayat Nasa'i, No. 52.)

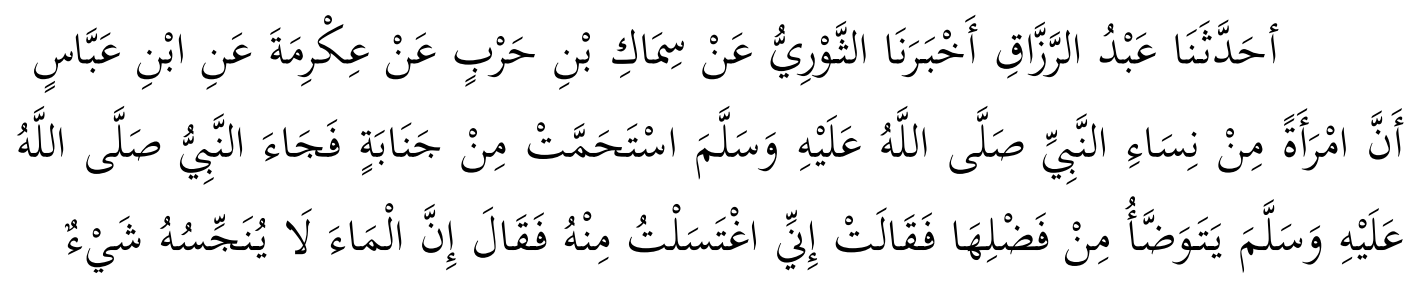

Artinya: Telah menceritakan kepada kami Abdurrazzaq telah mengabarkan kepada kami Ats Tsauri dari Simak bin Harb dari Ikrimah dari Ibnu Abbas; bahwa salah seorang dari istri Nabi shallallahu 'alaihi wasallam mandi janabah, lalu Nabi shallallahu 'alaihi wasallam berwudlu dari sisa air mandinya, kemudian ia berkata; "Tadi aku mandi dari air itu." Beliau pun bersabda: "Sesungguhnya air itu tidak dapat dinajiskan oleh sesuatu pun." (Hadits Riwayat Ahmad No. 2435).

Peneliti mengambil satu hadits dari setiap periwayat dengan tiga poin penting yang telah disebutkan diatas agar lebih mudah menganalisisnya. Isi teks naskah ini dianalisis dengan menggunakan teori hermeneutika (interpretasi) Gracia. Dengan melihat hadits yang ada dalam bunyi teks naskah diatas. Gracia mengatakan bahwa interpretasi tidak hanya sekedar menjelaskan atau mengembangkan makna dari teks, akan tetapi interpretasi seharusnya juga mengandung teks yang ditafsirkan (Gracia, 1995). Sehingga interpretasi menurut Gracia melibatkan tiga hal, yaitu (1) teks yang ditafsirkan (interpretandum), (2) penafsir, dan (3) keterangan tambahan (interpretans).

Jorge J.E. Gracia dalam bukunya A Theory of Textuality mengenalkan sebuah teori interpretasi yang dikenal dengan teori fungsi interpretasi (interpreter's function). Fungsi umum interpretasi adalah menciptakan di benak audiens kontemporer pemahaman terhadap teks yang sedang 
ditafsirkan (Almirzanah \& Syamsuddin (ed), 2011). Fungsi ini oleh Gracia dibagi ke dalam tiga macam fungsi spesifik yang dapat mempengaruhi bentuk-bentuk pemahaman, yaitu fungsi historis (historical function), fungsi makna (meaning function), dan fungsi implikatif (implicative function).

Berikut penjelasan lebih lanjut mengenai ketiga fungsi tersebut serta aplikasinya pada dua hadits yang terdapat di dalam isi teks Naskah tersebut diatas :

1. Historical Function (Fungsi Historis) bertujuan untuk menciptakan kembali di benak pembaca kontemporer pemahaman yang dimiliki oleh pengarang teks dan audiens historis, pada fungsi ini penafsir menghadirkan pemahaman yang dapat membawa pembaca teks kontemporer seolah hadir ke masa lampau ketika teks tersebut hadir. Dalam hadits Nasa'i No. 52 ini, jika kita menarik kembali kepada konteks pemahaman hadits pada masa ketika hadits tersebut turun, maka diketahui bahwa hadits ini muncul ketika Rasulullah shallallahu 'alaihi wasallam ditanya tentang hukum air yang berada di tanah lapang dan air yang dijilat oleh binatang melata dan binatang buas?" maka beliau pun menjawab: "Jika air itu mencapai dua qullah (tempayan besar) maka ia tidak akan najis karena sesuatu." Telah menceritakan kepada kami 'Amru bin Rafi' berkata, telah menceritakan kepada kami Abdullah Ibnul Mubarak dari Muhammad bin Ishaq dari Muhammad bin Ja'far dari Ubaidullah bin Abdullah bin Umar dari Bapaknya dari Nabi shallallahu 'alaihi wasallam sebagaimana hadits diatas. Adapun dalam hadits kedua yang diriwayatkan oleh Ahmad No. 2435 muncul ketika salah seorang dari istri Nabi shallallahu 'alaihi wasallam mandi janabah, lalu Nabi shallallahu 'alaihi wasallam berwudlu dari sisa air mandinya, kemudian ia berkata; "Tadi aku mandi dari air itu." Beliau pun bersabda: "Sesungguhnya air itu tidak dapat dinajiskan oleh sesuatu pun."

2. Meaning Function (Fungsi Makna) bertujuan untuk menciptakan suatu pemahaman di benak audiens kontemporer yang mungkin melampaui pemahaman yang dimiliki oleh pengarang historis dan audiens historis teks, dengan cara memunculkan aspek-aspek makna teks yang belum diketahui oleh pengarang dan audiens historis. Jika kita melihat kedua hadits diatas berdasarkan teori ini, maka dapat diketahui 
bahwa ide dasar dari hadits ini merupakan panggilan moral bagi masyarakat Muslim untuk lebih memperhatikan mana air yang beleh untuk bersuci dan mana yang tidak. Pemaknaan dari air yang boleh tersebut tidak lagi dimaknai secara sempit menurut konteks diturunkannya hadits tersebut tetapi pemahamannya akan lebih meluas jika kita menariknya pada konteks modern saat ini, maka bukan hanya hewan kucing saja, tetapi hewan lain yang ada disekitar kita selain anjing dan babi maka itu tidak najis jika bersuci menggunakan air sisa dari hewan tersebut.

3. Implicative Function (Fungsi Implikatif) dapat dipahami sebagai upaya memunculkan suatu pemahaman di benak audiens kontemporer sehingga mereka memahami implikasi dari makna teks yang ditafsirkan. Adapun implikasi dari teks hadits ini adalah memerintahkan kepada manusia untuk tidak menyepelekan hal yang sekecil apapun, mengingat banyak orang yang hanya melihat hadits berdasarkan konteks saat hadits itu muncul saja, akan tetapi implikasi dari hadits tersebut tetap diindahkan dengan konteks yang lain di dunia modern saat ini.

\section{Kesimpulan}

Berdasarkan hasil analisis yang dimulai dari suntingan teks, transliterasi, terjemah hingga ke tahap analisis isi teks naskah, dapat disimpulkan bahwa naskah "Syarah Muqoddimah al-Imam Bafadal alHadramy Li al-Haitami Fasal al-Ma'u al-Musta'mal Wa Fasal fi Ma'i anNajsi wa Nahwihi." merupakan naskah yang berisi tentang kitab fiqih dengan berbagai pembahasan. Dari segi analisis isi ditemukan asbabul wurud dari hadits yang membahas tiga hal tersebut dari berbagai periwayat, dalam teori interpretasi Gracia disebut dengan istilah historical function, dan juga didapatkan meaning function dari hadits tersebut untuk selalu menjaga kenajisan, serta dari segi implicative function didapatkan implikasi kepada kehidupan modern saat ini agar lebih berhati-hati dalam bersuci. 


\section{Referensi}

Almirzanah, S., \& Syamsuddin Sahiron (ed). (2011). Pemikiran Hermeneutika dalam Tradisi Barat: Reader. Yogyakarta: Lembaga Penelitian UIN Sunan Kalijaga.

Basuki. (2004). Pengantar Filologi. Semarang: Fasindo.

Darsa, U.A. (2013). Kodikologi: DInamika Identifikasi, Inventarisasi, dan Dokumentasi Tradisi Pernaskahan Sunda. Bandung: Fakultas Ilmu Budaya, Universitas Padjadjaran.

Depag RI. (2003). Pedoman Transliterasi Arab-Latin. Jakarta: Badan Litbang Agama dan Diklat Keagamaan.

Depdikbud. (1997). Kamus Besar Bahasa Indonesia. Jakarta: Balai Pustaka.

Erlina. (2015). Kajian Filologi Terhadap Teks Manuskrip Karya Ulama Lampung Ahmad Amin al-Banjary, Jurnal al-Bayan, 7 (1),

Fathurahman, O. (2015). Filologi Indonesia: Teori dan Metode. Jakarta: Prenada Media.

Gracia, J.J. E. (1995). A Theory Of Textuality: The Logic And Epistemology. Albany: State University Of New York Press.

Ibrahim, A, Ahmad. D.A, \& Nurhayati. M.T. (2019). Wasiat Rasulullah Kepada Ali Bin Abi Thalib Dalam Naskah Wasiyyah al-Mustafa: Edisi Teks dan Terjemahan. Jurnal Jumantra, 10 (2)

Koentjaraningrat. (1977). Metode-Metode Penelitian Masyarakat. Jakarta: Gramedia.

Kosasih, A., \& Supriatna, A. (2014). Pengantar Penelitian Filologi. Cileunyi: Semiotika.

Ma'luf, L. (1986). Al-Munjid fil Lughah. Beirut: Darul Masyriq.

Saduddin, I. (2017). Tajdid Hadfi al-Soufiyyah al-Ifradiyyah wa alGhaibiyyah Ila al-Ijtima'iyyah wa al-Tajribah fi Makhtutah Khaqiqah al-Ma'rifah (Dirasah Filolojiyyah wa Takhliliyyah). Jurnal Al-Bayan, 9(2), 33-46.

Saputra, K. H. (2008). Pengantar Filologi Jawa. Jakarta: Penerbit Wedatama Widya Sastra.

Sudjiman, P. (1995). Filologi Melayu. Jakarta: Pustaka Jaya.

Tjandrasasmita, U. (2006). Kajian Naskah-Naskah Klasik dan Penerapan bagi kajian Sejarah Islam di Indonesia. Jakarta: Puslitbang Lektur Keagamaan, Badan Libang dan Diklat Departemen RI. 